\title{
ENVIRONMENTAL LEVIES AND DISTORTIONARY TAXATION: PIGOU, TAXATION, AND POLLUTION
}

\author{
Gilbert E. Metcalf
}

Working Paper 7917

http://www.nber.org/papers/w7917

\author{
NATIONAL BUREAU OF ECONOMIC RESEARCH \\ 1050 Massachusetts Avenue \\ Cambridge, MA 02138 \\ September 2000
}

I appreciate comments from A. Lans Bovenberg and Don Fullerton on an earlier version of this note. I am also grateful for support from a National Science Foundation grant (SBR-9811324) through the National Bureau of Economic Research. The views expressed are those of the author and not necessarily those of the National Bureau of Economic Research.

(C) 2000 by Gilbert E. Metcalf. All rights reserved. Short sections of text, not to exceed two paragraphs, may be quoted without explicit permission provided that full credit, including $(\mathcal{C}$ notice, is given to the source. 
Environmental Levies and Distortionary Taxation:

Pigou, Taxation, and Pollution

Gilbert E. Metcalf

NBER Working Paper No. 7917

September 2000

JEL No. H21, H23, Q28

\title{
ABSTRACT
}

Bovenberg and de Mooij (1994) showed that, in the presence of preexisting distorting taxes, the optimal pollution tax typically lies below social marginal damages. Many have viewed this result as a refutation of the so-called "double dividend hypothesis," which suggests that a tax on pollution can both improve the environment and reduce distortions in the tax system. Bovenberg and de Mooij's paper triggered a large literature on optimal environmental tax rates in a second-best world.

In this note, I argue that the emphasis on tax rates is misguided. Using an analytical general equilibrium model, I show that for reasonable parameter values, an increase in tax distortions (arising from an increase in required tax revenues) leads to a fall in the optimal Pigouvian tax rate even while environmental quality improves. In general, knowledge of the direction of changes in optimal environmental tax rates due to changes in the economy is not sufficient for understanding the impact on environmental quality.

\author{
Gilbert E. Metcalf \\ Department of Economics \\ Tufts University \\ Medford, MA 02155 \\ and NBER \\ gilbert.metcalf@tufts.edu
}




\section{Introduction}

The double dividend hypothesis suggests that a tax on pollution can both improve the environment and reduce distortions in the tax system. In an important article, Bovenberg and de Mooij (1994) reframed the hypothesis as a question of whether the optimal tax on pollution in a second best world is higher or lower than the social marginal damages of pollution. In that paper, they "demonstrate that, in the presence of preexisting distorting taxes, the optimal pollution tax typically lies below the Pigovian tax, which fully internalizes the marginal social damage from pollution" (p. 1085).

I argue in this note that the focus on tax rates is misguided. ${ }^{1}$ A more important issue is the relation between the level of tax distortions in the economy and the amount of environmental quality. Moreover, knowing that the optimal pollution tax falls below social marginal damages does not imply that environmental quality falls in the presence of preexisting tax distortions. In effect, we should distinguish between "price" questions and "quantity" questions. The price question refers to tax rates while the quantity question refers to the amount of environmental quality. Framed this way, this note evokes Atkinson and Stern (1974) and their analysis of public good provision in a second best world. Atkinson and Stern first showed how the Samuelson Condition for pure public goods is affected by the presence of distortionary taxes (a "price" question). They then showed how the optimal provision of the pure public good is affected by distorting taxes (a "quantity" question). A key message in their paper is that answering the question of how the Samuelson Condition changes tells us nothing about the optimalprovision of

1 The emphasis on tax rates can also be found in a number of papers that followed Bovenberg and de Mooij, including Fullerton (1997), Schob (1997), and Jaeger (1999). 
the public good. This note gives a similar message in the environmental policy arena (hence the sub-title of the note which plays off the title of Atkinson and Stern's paper).

Specifically, I show that the optimal environmental tax component of a commodity tax on a polluting good falls short of social marginal damages and that this environmental tax component falls as revenue needs (and hence tax distortions) rise. The fact that the environmental tax falls might lead one to believe that environmental quality would also fall as revenue needs rise. (One might also draw this conclusion from Bovenberg and de Mooij when they note that "high costs of public funds crowd out not only ordinary public consumption, but also the collective good of the environment" (p. 1088).) Instead, I show that the response of environmental quality to an increase in the revenue requirement depends on two effects: (1) a substitution effect, as consumers substitute from clean to dirty goods as the environmental tax component falls, and (2) an output effect, as consumers substitute from purchased commodities to leisure (here assumed to be a clean good). For all reasonable parameter values, I find that the output effect dominates the substitution effect so that an increase in required revenues improves the environment while simultaneously reducing the optimal Pigouvian tax increment.

\section{The Model and Optimal Tax Rates}

In this section, I first present the model and then solve for optimal tax rates on the clean and dirty good taking into account the environmental externality. I also solve for the optimal amount of environmental quality. In the next section, I carry out comparative statics on these optimum prices and quantities to examine how increases in required government revenue affect both the optimal Pigouvian tax increment as well as the optimal amount of environmental quality. 
Following Bovenberg and de Mooij, I employ a linear production technology in which labor (L) is used to produce a clean good (C), a dirty good (D), and government services (G). Government services can be either clean or dirty, and I assume that the fraction of these services that contribute to pollution is constant and equal to $\gamma$. The economy has $\mathrm{N}$ identical individuals and labor productivity equals $\mathrm{h}$. Since each good is produced using one unit of labor, the technology is

$$
\mathrm{NhL}=\mathrm{NC}+\mathrm{ND}+\mathrm{G}
$$

Utility is a function of the two goods and government services as well as leisure (V) and environmental quality $(\mathrm{E})$ :

$$
\mathrm{U}=\mathrm{u}(\mathrm{C}, \mathrm{D}, \mathrm{V} ; \mathrm{G}, \mathrm{E})
$$

where environmental quality is a function of the aggregate production of the dirty good and the government good: $\mathrm{E}=\mathrm{e}(\mathrm{ND}+\gamma \mathrm{G})$, with $\mathrm{e}^{\prime}<0$. Individuals maximize utility subject to a time constraint $(\mathrm{V}+\mathrm{L}=1)$ and a budget constraint:

$$
\mathrm{hL}=\left(1+\mathrm{t}_{\mathrm{C}}\right) \mathrm{C}+\left(1+\mathrm{t}_{\mathrm{D}}\right) \mathrm{D}
$$

where $t_{C}$ is a tax on $C$ and $t_{D}$, a tax on $D$. The social marginal damage of pollution in dollar terms $(\tau)$ is the marginal damage divided by the private marginal utility of income $(\lambda)$ :

$$
\tau=-\frac{\partial U}{\partial E} e^{\prime} N / \lambda
$$

As in Fullerton (1997), I first solve for optimal tax rates conditional on some level of required government services $(G)$. To do this, first consider a small increase in $t_{D}$ combined with a revenue-neutral reduction in $\mathrm{t}_{\mathrm{C}}$. I totally differentiate the utility function, plug in the first order conditions from the household's utility maximization problem and the resource constraint $(\mathrm{dL}=\mathrm{dC}+\mathrm{dD})$, and obtain a measure of the welfare 
gain from increasing $t_{D}$ while the tax rate on $C$ is reduced to keep total tax revenues constant:

$$
\mathrm{dU} / \lambda=\mathrm{t}_{\mathrm{C}} \mathrm{dC}+\left(\mathrm{t}_{\mathrm{D}}-\tau\right) \mathrm{dD}
$$

Setting the left hand side of equation (5) equal to zero to solve for the optimal tax rate on D relative to that on $\mathrm{C}$, I get ${ }^{2}$

$$
\mathrm{t}_{\mathrm{D}}^{*}=\tau+\left(-\frac{\mathrm{dC}}{\mathrm{dD}}\right) \mathrm{t}_{\mathrm{C}}^{*}
$$

Perturbing the tax rates will generate changes in all the variables in a general equilibrium. Thus, I need a complete model in order to determine the changes in C and D to obtain a closed form solution for the relation between $t^{*}{ }_{C}$ and $t^{*}{ }_{D}$ in equation (6).

First consider the consumer response to a change in price. Following the approach taken by the previous authors, I assume a subutility function for C and D that is homothetic and weakly separable from leisure. Let this function be Q(C,D). With this assumption, I can characterize the preference for C and D in terms of the elasticity of substitution in consumption $(\sigma)$ :

$$
\hat{\mathrm{C}}-\hat{\mathrm{D}}=\sigma\left(\hat{\mathrm{t}}_{\mathrm{D}}-\hat{\mathrm{t}}_{\mathrm{C}}\right)
$$

where hats indicate proportional changes $\left(\hat{\mathrm{C}}=\frac{\mathrm{dC}}{\mathrm{C}}\right)$ and in the case of the tax variables, $\hat{\mathrm{t}}=\frac{\mathrm{dt}}{1+\mathrm{t}}$. In other words, $\hat{\mathrm{t}}$ is the change in tax as a percentage of the consumer price. The consumer price for $C\left(\mathrm{p}_{C}\right)$ equals $1+t_{C}$, so $\hat{t}_{C}=\hat{p}_{C}$ (similarly for $\left.p_{D}\right)$. Labor earns a fixed gross wage of $\mathrm{h}$ and a real wage of $\mathrm{w}=\mathrm{h} / \mathrm{p}_{\mathrm{Q}}$, where $\mathrm{p}_{\mathrm{Q}}$ is a price index on the

\footnotetext{
2 This is equation (9) in Fullerton (1997).
} 
consumption bundle $\mathrm{Q}(\mathrm{C}, \mathrm{D})$. Labor supply is related to the real wage by the uncompensated labor supply elasticity $(\varepsilon)$ :

$$
\hat{\mathrm{L}}=\varepsilon \hat{\mathrm{W}} \text {. }
$$

The percentage change in the real wage depends on the change in tax rates:

$$
\hat{\mathrm{W}}=-\phi \hat{\mathrm{t}}_{\mathrm{C}}-(1-\phi) \hat{\mathrm{t}}_{\mathrm{D}}
$$

where $\phi$ is the share of consumer spending on the clean good.

Next, I turn to the government's budget constraint. Fixed government spending (G) is financed by taxes on the $\mathrm{N}$ identical households in the economy:

$$
\mathrm{t}_{\mathrm{C}} \mathrm{C}+\mathrm{t}_{\mathrm{D}} \mathrm{D}=\mathrm{G} / \mathrm{N}
$$

Differentiating (10) and keeping the level of G fixed, I obtain

$$
\phi\left(\hat{\mathrm{t}}_{\mathrm{C}}+\theta_{\mathrm{C}} \hat{\mathrm{C}}\right)+(1-\phi)\left(\hat{\mathrm{t}}_{\mathrm{D}}+\theta_{\mathrm{D}} \hat{\mathrm{D}}\right)=0
$$

where $\theta$ is the tax expressed as a fraction of the consumer price (e.g. $\theta_{C}=t_{C} /\left(1+t_{C}\right)$ ). The final equation follows from differentiating the overall resource constraint (1) and defining production shares $\pi_{\mathrm{C}}=\mathrm{C} / \mathrm{hL}$ and $\pi_{\mathrm{D}}=\mathrm{D} / \mathrm{hL}$ :

$$
\hat{\mathrm{L}}=\pi_{\mathrm{C}} \hat{\mathrm{C}}+\pi_{\mathrm{D}} \hat{\mathrm{D}}
$$

Equations (7) - (9), (11), and (12) are five equations from which I can solve for $\hat{C}, \hat{D}, \hat{L}, \hat{w}$, and $\hat{t}_{C}$ as functions of $\hat{t}_{D}$.

Some straightforward algebra leads to the general equilibrium response of $\mathrm{C}$ and $\mathrm{D}$ to a change in the tax on the dirty good:

$$
\begin{gathered}
\hat{C}=\frac{d C}{C}=\left(\frac{D}{C}\right) \frac{\sigma\left(1-\varepsilon t_{D}\right)\left(p_{C} C+p_{D} D\right)}{p_{C} C\left(1-\varepsilon t_{C}\right)+D\left(p_{C}\left(1-\varepsilon t_{D}\right)+\sigma\left(t_{D}-t_{C}\right)\right)} \hat{t}_{D} \\
\hat{D}=\frac{d D}{D}=-\frac{\sigma\left(1-\varepsilon t_{C}\right)\left(p_{C} C+p_{D} D\right)}{p_{C} C\left(1-\varepsilon t_{C}\right)+D\left(p_{C}\left(1-\varepsilon t_{D}\right)+\sigma\left(t_{D}-t_{C}\right)\right)} \hat{t}_{D}
\end{gathered}
$$


Substituting (13) and (14) into (6) yields a simple expression for the relationship between the optimal tax rates on $\mathrm{C}$ and $\mathrm{D}:^{3}$

$$
\mathrm{t}_{\mathrm{D}}^{*}=\mathrm{t}_{\mathrm{C}}^{*}+\left(1-\varepsilon \mathrm{t}_{\mathrm{C}}^{*}\right) \tau
$$

Now that I have a closed form solution for the optimal tax rate on D relative to that on $\mathrm{C}$, I can carry out an experiment in comparative statics and consider the effect of an increase in government expenditures $(\mathrm{G})$ on the level of the second-best optimal tax rates as well as on the amount of environmental quality in equilibrium. Before turning to this experiment, however, I note a few points about the optimal tax rates in (15). First, suppose that environmental tax revenues are sufficient to cover government expenses without a tax on the clean good $\left(\mathrm{t}^{*} \mathrm{C}=0\right)$. In this case, the tax on $\mathrm{D}$ (as well as the difference, $\left.t_{D}-t_{C}\right)$ exactly equals $\tau$. This is the Pigouvian rule in a first-best situation. Second, even if a tax on $\mathrm{C}$ is required, the first best rule still holds so long as $\varepsilon$ equals zero. Third, if neither of these conditions hold, then the Pigouvian tax increment $\left(t_{D}^{*}-t_{C}^{*}\right)$ falls short of $\tau$ so long as $\varepsilon t_{C}$ is positive. This confirms Bovenberg and de Mooij's result but avoids any possible confusion that might arise from implicit taxation of the dirty good through a tax on labor.

\section{The Impact on the Environment of Increasing Government Revenue}

Given the optimizing behavior described in the last section, I now turn to comparative statics. Imagine that the government needs to raise additional distortionary tax revenues to finance an expansion of government services. A natural question to ask is what happens to the difference between the Pigouvian tax increment $\left(t_{D}^{*}-t_{C}^{*}\right)$ and social

\footnotetext{
${ }^{3}$ Equation (15) and the government budget constraint in equation (10) will pin down both tax rates. I am only concerned here with the Pigouvian tax increment $t_{D}-t_{C}$.
} 
marginal damages $(\tau)$, a "price" question, as noted in the introduction. ${ }^{4}$ An early reading of the Double Dividend literature might suggest that this increment should rise as revenue needs rise. ${ }^{5}$ Instead, as we shall see, the increment falls. This suggests that the increase in required government revenues will lead to a dirtier environment (a "quantity" question), a concern presumably of greater interest to environmentalists than tax rates, per se. On the contrary, as I'll show below, the increase in required revenues likely leads to a cleaner environment.

Let me now turn to the policy experiment and these two questions. ${ }^{6}$ Specifically, I investigate how an increase in required distortionary taxes to finance an increase in $\mathrm{G}$ changes 1) the Pigouvian tax increment $\left(t_{D}^{*}-t_{C}^{*}\right)$ and 2) the optimal amount of environmental quality $(\mathrm{E})$. Note that the diversion of resources from the private to the public sector directly affects the environment to the extent that public services themselves may pollute more than the mix of private goods reduced. For example, if public services are entirely clean, the expansion of the government sector will likely lead to a cleaner environment since the increased government output has no impact on the environment. To avoid this demand side effect, I assume that government spends its revenue on the

\footnotetext{
${ }^{4}$ I treat $\mathrm{G}$ as an exogenous parameter while the tax rates are set in an optimal fashion. In other words, some political process leads to a choice of $\mathrm{G}$ and conditional on that choice, taxauthorities set tax rates to minimize deadweight loss.

5 For example consider this quotation from Repetto et al. (1992): "Taxes on these environmentally damaging activities [resource waste, pollution, and congestion] would not distort economic decisions, but rather would correct existing distortions" (page 2). Following this logic, the greater the distortion, the higher the tax rates on polluting activities.

6 In a recent paper, Gaube (1998) considers a slightly different experiment. He compares environmental quality in a first-best relative to a second-best optimum and finds that environmental quality is higher in the second-best optimum. To obtain this result, he restricts utility to be quasilinear in private consumption, leisure, the government good, and the environment. This restriction is stronger than the restrictions on preferences in this model. Instead of looking at two disparate points, this paper looks at small changes to address the question of the impact of increased tax distortions on environmental quality.
} 
same mix of clean and dirty goods as does the private economy. ${ }^{7}$ In other words, dirty government output is a fraction of $\mathrm{G}$ equal to

$$
\gamma \mathrm{G} \equiv \frac{\pi_{\mathrm{D}}}{\pi_{\mathrm{C}}+\pi_{\mathrm{D}}} \mathrm{G}
$$

where $\gamma$ is the fraction of $G$ that is dirty. Recall that $\pi_{C}\left(\pi_{D}\right)$ is the share of $C(D)$ in total production. Environmental quality will increase if $N D+\gamma G$ decreases. Differentiating this expression, environmental quality will increase if

$$
\left(1-\pi_{\mathrm{G}}\right) \hat{\mathrm{D}}+\pi_{\mathrm{G}} \hat{\mathrm{G}}<0
$$

where $\pi_{\mathrm{G}}=\mathrm{G} / \mathrm{NhL}$ and $\pi_{\mathrm{C}}+\pi_{\mathrm{D}}+\pi_{\mathrm{G}}=1$.

For the purposes of measuring the general equilibrium effects of an increase in G, equations (7), (8), and (10) continue to hold. Equation (11) now becomes

$$
\phi\left(\hat{\mathrm{t}}_{\mathrm{C}}+\theta_{\mathrm{C}} \hat{\mathrm{C}}\right)+(1-\phi)\left(\hat{\mathrm{t}}_{\mathrm{D}}+\theta_{\mathrm{D}} \hat{\mathrm{D}}\right)=\pi_{\mathrm{G}} \hat{\mathrm{G}}
$$

Equation (12) becomes

$$
\hat{\mathrm{L}}=\pi_{\mathrm{C}} \hat{\mathrm{C}}+\pi_{\mathrm{D}} \hat{\mathrm{D}}+\pi_{\mathrm{G}} \hat{\mathrm{G}}
$$

Finally, conditional on $\mathrm{G}$, equation (15) relating the optimal taxes on the clean and dirty goods continues to hold. Differentiating this equation yields

$$
\hat{\mathrm{t}}_{\mathrm{D}}=(1-\varepsilon \tau)\left(\frac{1+\mathrm{t}_{\mathrm{C}}}{1+\mathrm{t}_{\mathrm{D}}}\right) \hat{\mathrm{t}}_{\mathrm{C}} \text {. }
$$

These six equations can be solved for changes in $\mathrm{C}, \mathrm{D}, \mathrm{L}, \mathrm{t}_{\mathrm{C}}, \mathrm{t}_{\mathrm{D}}$, and $\mathrm{w}$ as functions of $\hat{\mathrm{G}}$. Let me first consider the question of the impact of an increase in $G$ on the Pigouvian tax increment. From equation (15) we see that

$$
\mathrm{d}\left(\mathrm{t}_{\mathrm{D}}-\mathrm{t}_{\mathrm{C}}\right)=-\varepsilon \tau \mathrm{dt}_{\mathrm{C}}
$$

7 This is the approach taken in Harberger (1962) to rule out demand side effects in his classic analysis of 
and the Pigouvian tax increment will fall if the tax rate on $\mathrm{C}$ rises as $\mathrm{G}$ increases.

Rewrite $(15)$ as $\mathrm{t}_{\mathrm{D}}^{*}=\tau+(1-\varepsilon \tau) \mathrm{t}^{*} \mathrm{C}$ and note that the sign of $\mathrm{dt}_{\mathrm{D}}$ equals the sign of $\mathrm{dt}_{\mathrm{C}}$ if $1-\varepsilon \tau>0$. With a high range estimate of $\varepsilon$ equal to 0.5 , the expression $1-\varepsilon \tau$ will be positive so long as $\tau<2$, or that the social marginal damages of pollution do not exceed twice the production cost of the dirty good. I'll assume that this condition holds. ${ }^{8}$ If we rule out any Laffer tax effects, then $\operatorname{sgn}\left(\mathrm{dt}_{\mathrm{D}}\right)=\operatorname{sgn}\left(\mathrm{dt}_{\mathrm{C}}\right)=\operatorname{sgn}(\mathrm{dG})>0$. With $\mathrm{dt}_{\mathrm{C}}>0$, equation (20) indicates that the Pigouvian tax increment falls as G rises (so long as $\varepsilon>0$ ). An increase in required distortionary tax revenues does not favor increased taxation of the dirty good relative to the clean good.

The intuition underlying this result is quite simple. Sandmo (1975) showed that the optimal tax on a polluting good is a weighted average of a Ramsey component and marginal environmental damages (MED). As government revenue needs increase, the weight on the Ramsey component rises and the weight on the environmental component falls. With separability between leisure and consumption goods, the optimal Ramsey components on the two goods are equal. Thus an increase in the Ramsey weight leads to a decrease in the difference between the two tax rates (i.e. the Pigouvian tax increment).

Having answered the "price" question, I now turn to the "quantity" question.

Recall that environmental quality rises if $\left(1-\pi_{G}\right) \hat{D}+\pi_{G} \hat{G}<0$ (equation (18)). Some simple manipulation of the six equations in our system shows that

$$
\left(1-\pi_{G}\right) \hat{D}+\pi_{G} \hat{G}=\pi_{C} \sigma\left(\hat{t}_{C}-\hat{t}_{D}\right)+\hat{L}
$$


Thus, $d E>0 \Leftrightarrow \pi_{C} \sigma\left(\hat{t}_{C}-\hat{t}_{D}\right)+\hat{L}<0$. The first term on the right hand side of (21) is positive, since the Pigouvian tax increment falls, ${ }^{9}$ and the second term is negative since labor supply falls in response to the lower real wage. ${ }^{10}$ The first term is a substitution effect. As the Pigouvian tax increment falls, consumers will substitute from $\mathrm{C}$ to $\mathrm{D}$. The strength of this effect depends on the elasticity of substit ution in consumption $(\sigma)$. The substitution effect will work towards reducing environmental quality. The second term is an output effect and reflects the fact that the increase in taxation will lead to a substitution away from both produced goods towards leisure. Since leisure is a clean commodity, this effect serves to improve environmental quality. Whether an increase in government spending financed by increased taxes leads to a fall or rise in environmental quality depends on the relative size of the substitution and output effects. ${ }^{11}$

To get a feel for the relative importance of the substitution and output effects, consider the following numerical example where I assume an economy with the characteristics listed in Table $1 .^{12}$

\footnotetext{
${ }^{9} \hat{\mathrm{t}}_{\mathrm{D}}=(1-\varepsilon \tau)\left(\frac{1+\mathrm{t}_{\mathrm{C}}}{1+\mathrm{t}_{\mathrm{D}}}\right) \hat{\mathrm{t}}_{\mathrm{C}} \equiv \Omega \hat{\mathrm{t}}_{\mathrm{C}}$ where $\Sigma<1$ since $\mathrm{t}_{\mathrm{D}}>\mathrm{t}_{\mathrm{C}}$ and $1-\varepsilon \tau<1$. Thus $\hat{\mathrm{t}}_{\mathrm{D}}-\hat{\mathrm{t}}_{\mathrm{C}}=(\Omega-1) \hat{\mathrm{t}}_{\mathrm{C}}<0$.

10 The real wage falls since the optimal taxes on both C and D increase. See equation (9).

11 Bovenberg and van der Ploeg (1994) carry out a similar exercise and derive an equation similar to equation (21). See Table 4 in that paper. The advantage of this derivation is that 1) it abstracts from any demand side effects, 2) the formula is considerably more transparent, and 3) I can easily provide some numerical results to show the relative magnitude of the two effects (see below).

12 See Fullerton and Metcalf (2000) for a justification for these assumptions.
} 


\begin{tabular}{|c|c|}
\hline \multicolumn{2}{|c|}{$\begin{array}{c}\text { Table 1: Parameter } \\
\text { Assumptions }\end{array}$} \\
\hline Parameter & Value \\
\hline$\varepsilon$ & 0.30 \\
\hline$\tau$ & 0.30 \\
\hline$\pi_{\mathrm{C}}$ & 0.30 \\
\hline$\pi_{\mathrm{D}}$ & 0.40 \\
\hline$\pi_{\mathrm{G}}$ & 0.30 \\
\hline$\sigma$ & 1.0 \\
\hline
\end{tabular}

With these parameter values, the optimal tax rates are $\mathrm{t}^{*}{ }_{\mathrm{C}}=0.27, \mathrm{t}_{\mathrm{D}}^{*}=0.55$, and the Pigouvian tax increment is $0.28<\tau$. Now consider a 10 percent increase in required government revenue. The Pigouvian tax increment falls by .0066. This induces a substitution effect equal to 0.005 . Meanwhile, the output effect equals -0.015 , so the total effect is -0.010 . In other words, the 1.5 percent fall in labor supply will more than offset the substitution effect, and pollution falls by 1 percent. ${ }^{13}$ Table 2 presents a range of estimates of the impact of a 10 percent increase in required revenue on the Pigouvian tax increment while Table 3 shows the impact on the amount of pollution, for differing values of $\sigma$ and $\varepsilon$ :

\begin{tabular}{|c|c|c|c|c|}
\hline \multirow{5}{*}{$\sigma$} & & \multicolumn{3}{|c|}{$\varepsilon$} \\
\hline & & 0.15 & 0.30 & 0.45 \\
\hline & 0.5 & -0.0030 & -0.0066 & -0.0110 \\
\hline & 1.0 & -0.0030 & -0.0066 & -0.0109 \\
\hline & 2.0 & -0.0029 & -0.0065 & -0.0107 \\
\hline
\end{tabular}

13 The improvement in environmental quality depends importantly on the relationship between leisure and pollution. I have made the extreme assumption that leisure is an entirely clean activity. This is clearly not entirely accurate. Changing this assumption does not alter my main message: no conclusion can be drawn as to changes in the amount of environmental quality given a particular change in the Pigouvian tax increment. 


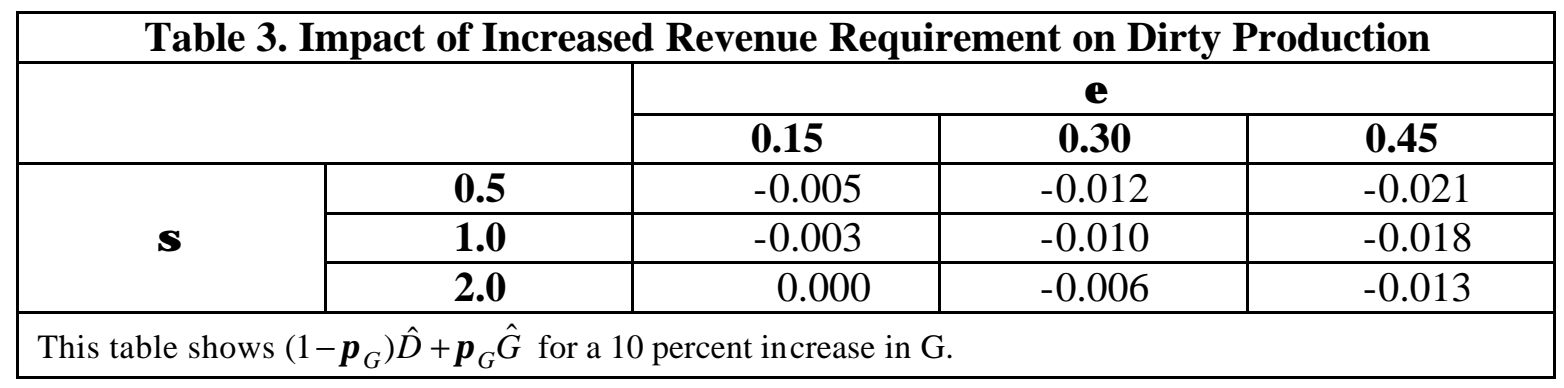

The Pigouvian tax increment falls in every case while environmental quality nearly always rises. Only in the case of an elasticity of substitution equal to 2 combined with a low labor supply elasticity $(0.15)$ does the increased revenue requirement fail to reduce pollution. In all other cases, pollution falls between .3 and 2.1 percent.

\section{Conclusion}

This note has accomplished two goals. First, it has confirmed in a simple model that the optimal incremental tax on pollution lies below social marginal damages with pre-existing distorting taxes and that the optimal environmental tax increment falls as government revenue needs rise. Second, I have shown that an increase in government revenue needs has two offsetting impacts on the environmental quality. For reasonable parameter values, environmental quality improves despite the decrease in the Pigouvian tax increment.

This result evokes Atkinson and Stern's analysis of public good provision in a second best world. The first part of their paper focused on how the Samuelson Condition for pure public goods is altered in the presence of distortionary taxation. That question is analogous to the current focus on the relationship between the environmental tax increment $\left(t_{D}-t_{C}\right)$ and social marginal damages $(\tau)$. Atkinson and Stern then pointed out that answering the question of how the Samuelson Condition changes (a price question) tells us nothing about the optimal provision of the public good (a quantity question). 
Similarly, here learning that the optimal tax increment falls increasingly short of social marginal damages as the need for distortionary taxes rises does not imply that environmental quality must fall as revenue needs increase. On the contrary, a quite plausible result is a cleaner environment. In short, the focus on tax rates is misleading, and attention should be paid to how pollution itself is altered by changes in the need for distorting taxes. 


\section{References}

Atkinson, A. and Stern, N., 1974. Pigou, taxation, and public goods. Review of Economic Studies 41, 119-128.

Bovenberg, A. L. and de Mooij, R., 1994. Environmental levies and distortionary taxation. American Economic Review 94, 1085-1089.

Bovenberg, A. L. and van der Ploeg, F., 1994. Environmental policy, public finance and the labour market in a second-best world. Journal of Public Economics 55 (3), 349-390.

Fullerton, D., 1997. Environmental levies and distortionary taxation: Comment. American Economic Review 87 (1), 245-251.

Fullerton, D. and Metcalf, G. E., 2000. Environmental controls, scarcity rents, and preexisting distortions. Journal of Public Economics forthcoming,

Gaube, T., 1998. Distortionary taxes preserve the environment, Discussion Paper No. A579, Department of Economics, University of Bonn, Bonn.

Harberger, A. C., 1962. The incidence of the corporation income tax. Journal of Political Economy 70 (3), 215-240.

Jaeger, W., 1999. Double dividend reconsidered, Williams College, Williamstown, MA.

Repetto, R., Dower, R. C., Jenkins, R. and Geoghegan, J., 1992. Green fees: How a tax shift can work for the environment and the economy, World Resources Institute, Washington, DC.

Sandmo, A., 1975. Optimal taxation in the presence of externalities. Swedish Journal of Economics 77, 86-98.

Schob, R., 1997. Environmental taxes and pre-existing distortions: The normalization trap. International Tax and Public Finance 4 (2), 167-176. 